\title{
Spiroplasma diabroticae sp. nov., from the Southern Corn Rootworm Beetle, Diabrotica undecimpunctata (Coleoptera: Chrysomelidae)
}

PATRICIA CARLE,${ }^{1}$ ROBERT F. WHITCOMB,${ }^{2 *}$ KEVIN J. HACKETT,${ }^{3}$ JOSEPH G. TULLY, ${ }^{4}$ DAVID L. ROSE, ${ }^{4}$ JOSEPH M. BOVE, ${ }^{1}$ ROBERTA B. HENEGAR, ${ }^{3}$ MEGHNAD KONAI, ${ }^{3}$ AND DAVID L. WILLIAMSON ${ }^{5}$

\begin{abstract}
Laboratoire de Biologie Cellulaire et Moléculaire, Institut Nationale de Recherche Agronomique, and Université Bordeaux II, 33883 Villenave d'Ornon, France ${ }^{1}$; Vegetable Laboratory, ${ }^{2}$ and Insect Biocontrol Laboratory, ${ }^{3}$ U.S. Department of Agriculture, Beltsville, Maryland 20705; Mycoplasma Section, Laboratory of Molecular Microbiology, National Institute of Allergy and Infectious Diseases, Frederick Cancer Research Facility, Frederick, Maryland 217024; and Department of Anatomical Sciences, State University of New York, Stony Brook, New York 117945
\end{abstract}

\begin{abstract}
Spiroplasma strain DU-1 ${ }^{\mathrm{T}}(\mathrm{T}=$ type strain), which was isolated from hemolymph of the corn rootworm Diabrotica undecimpunctata (Coleoptera: Chrysomelidae), was serologically distinct from other spiroplasma species, groups, and subgroups. Cells of strain DU-1 ${ }^{\mathrm{T}}$ were shown by light microscopy to be helical motile filaments. Electron microscopy revealed cells bounded by a single cytoplasmic membrane, with no evidence of a cell wall. The organism was not sensitive to $500 \mathrm{U}$ of penicillin per mI. Strain DU-1 ${ }^{\mathrm{T}}$ grew well in SM-1, M1D, and SP-4 liquid media, in broth supplemented with $1 \%$ bovine serum fraction or conventional horse serum, and under both aerobic and anaerobic conditions. This organism did not appear to have a sterol requirement for growth, as has been reported for several other Spiroplasma species or strains. Optimal growth occurred at $32^{\circ} \mathrm{C}$, with a doubling time of $0.9 \mathrm{~h}$; strain DU-1 ${ }^{\mathrm{T}}$ multiplied at 10 to $41^{\circ} \mathrm{C}$ but failed to grow at 5 or $43^{\circ} \mathrm{C}$. It produced acid from glucose but hydrolyzed neither arginine nor urea. The results of reciprocal serologic tests in which antigens or antisera to established Spiroplasma species, groups, subgroups, and putative groups were used indicated that strain DU-1 ${ }^{\mathrm{T}}$ was serologically distinct. This organism has a DNA guanine-plus-cytosine content of $25 \pm 1 \mathrm{~mol} \%$ and a genome size of $1,350 \mathrm{kbp}$. Strain $\mathrm{DU}-1^{\mathrm{T}}$ is a member of a cluster of fast-growing insect-associated spiroplasmas, as determined by sequence analysis of 16S rRNA. On the basis of the results of this study and previously published data, strain DU-1 (= ATCC 43210) is designated the type strain of a new species, Spiroplasma diabroticae.
\end{abstract}

Members of the genus Spiroplasma $(19,25)$ are universally associated with arthropods and, in most instances, insects (3, 5). Spiroplasma strain DU-1 ${ }^{\mathrm{T}}$ ( $\mathrm{T}=$ type strain) was isolated from the hemolymph of an adult southern corn rootworm beetle, Diabrotica undecimpunctata howardi (Coleoptera: Chrysomelidae), collected on alfalfa in late November in Maryland $(3,4)$. Larvae of this insect feed on the roots of corn and other grasses, but adults feed on various plant tissues, often causing economic damage. Isolation of spiroplasma strain DU $-1^{\mathrm{T}}$ from an economically important insect focused attention on its possible use in biological control of insects (6). In 1987, strain DU-1 ${ }^{\mathrm{T}}$ was classified as a group XII organism in the spiroplasma group classification system (18). In this paper we report fulfillment of the minimum standards for species descriptions (8) and name strain DU-1 ${ }^{\mathrm{T}}$ (= ATCC $43210^{\mathrm{T}}$ ) Spiroplasma diabroticae.

\section{MATERIALS AND METHODS}

Spiroplasma strains. The techniques used to isolate strain DU $-1^{\mathrm{T}}$ from insects have been described previously $(10)$. Strain DU-1 ${ }^{\mathrm{T}}$ was isolated from the hemolymph of an adult southern corn rootworm beetle, $D$. undecimpunctata howardi (Coleoptera: Chrysomelidae), collected on alfalfa in late November in Maryland. The strain was purified by conventional filtration-cloning (15). Representative strains of previously recognized spiroplasma groups and subgroups and tentative new groups $(17-19,23,25)$, including the type strains of all species, were also used in this study.

* Corresponding author. Mailing address: Vegetable Laboratory, GH3-1, Building 010, R2 BARCW, Beltsville, MD 20705. Phone: (301) 504-8339. Fax: (301) 504-6017.
Culture medium and cultivation techniques. Strain DU-1 ${ }^{T}$ was grown in primary culture in SM-1 liquid medium (21) at room temperature. After several broth passages the isolate was lyophilized. For characterization studies, an early line was revived and passaged twice at $30^{\circ} \mathrm{C}$ before cloning. Following cloning, representative strain DU- $1^{\mathrm{T}}$ was used in characterization studies. Other culture media employed (21) included M1D and SP-4 media and broth medium supplemented with horse serum or $1 \%$ bovine serum fraction (14). A solid formulation of SP-4 medium was prepared by adding Noble agar (Difco Laboratories, Detroit, Mich.) to a final concentration of $2.25 \%$. Agar cultures of strain DU-1 ${ }^{\mathrm{T}}$ were incubated at $30^{\circ} \mathrm{C}$ either aerobically with $5 \%$ carbon dioxide (GasPak system; BBL Microbiology Systems, Cockeysville, Md.) or anaerobically (Hydrogen GasPak system). Temperature requirements for growth were assessed as previously reported (9).

Morphological studies. Cells of strain DU- ${ }^{\mathrm{T}}$ in the logarithmic phase were examined by dark-field microscopy at a magnification of $\times 1,250$. The ultrastructure of strain DU-1 ${ }^{\mathrm{T}}$, as demonstrated by electron microscopy, has been reported previously (18).

Sterol requirement. The sterol requirements for growth of strain DU-1 ${ }^{\mathrm{T}}$ were assayed by a standard broth culture method $(11,14)$ or by testing the ability of the strain to maintain sustained growth in various serum- or Tween 80 -supplemented media (12).

Biological and biochemical properties. The procedures used to assess carbohydrate fermentation and arginine and urea hydrolysis have been described previously (1). Filtration characteristics were determined in M1D broth by previously described techniques (15).

Serological tests. Antiserum to strain $\mathrm{DU}-1^{\mathrm{T}}$ was produced in rabbits as previously described (26). Hyperimmune antisera to all previously established Spiroplasma species and groups and putative groups and subgroups (17) were obtained from reference collections at the Beltsville Agricultural Research Center and the National Institute of Allergy and Infectious Diseases laboratory in Frederick, Md. Reference spiroplasma antigens and antisera were tested against strain DU-1 ${ }^{\mathrm{T}}$ antigen and antiserum in reciprocal serological tests by using both metabolism inhibition and deformation techniques $(24,26)$.

Genomic analysis. The DNA base composition (guanine-plus-cytosine content) and genome size of strain DU-1 $1^{\mathrm{T}}$ have been reported previously $(2,18)$.

Nucleotide sequence accession number. The $16 \mathrm{~S}$ rRNA nucleotide sequence accession number of strain DU- $1^{\mathrm{T}}$ is $\mathrm{M} 24482$. 


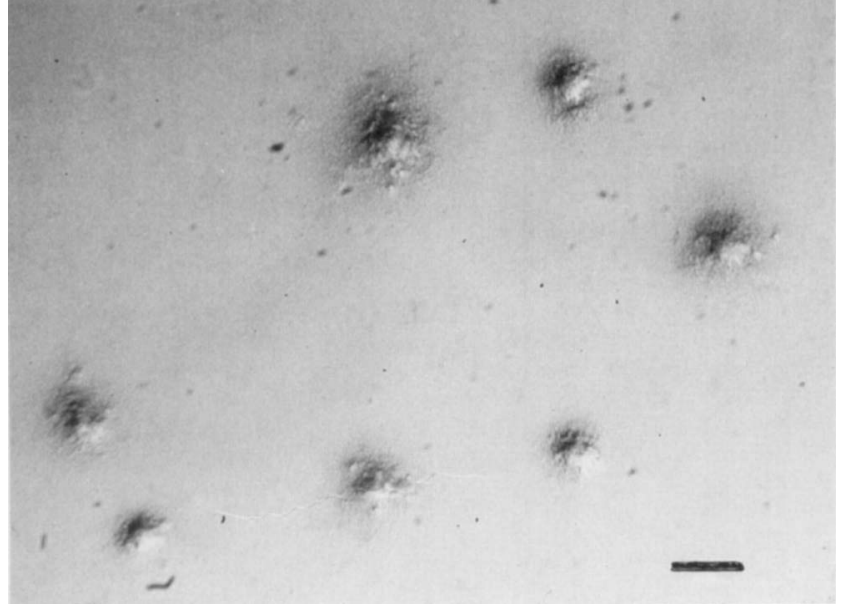

FIG. 1. Colonies of strain DU-1 ${ }^{\mathrm{T}}$ on SP-4 medium containing $2.25 \%$ Noble agar after 3 days of incubation at $30^{\circ} \mathrm{C}$ in an anaerobic environment. Bar $=100$ $\mu \mathrm{m}$.

\section{RESULTS AND DISCUSSION}

Cultural and morphological properties. Strain DU-1 ${ }^{\mathrm{T}}$ grew well in liquid SM-1, M1D, or SP-4 medium and on solid media prepared from these formulations. It also grew in the Edward formulation of conventional mycoplasma medium containing 15 to $20 \%$ horse serum or in mycoplasma medium containing $1 \%$ bovine serum fraction. The doubling times at $10,15,20,25$, $30,32,37$, and $41^{\circ} \mathrm{C}$ were $33.1,9.2,3.7,2.1,1.7,0.9,1.7$, and $9.4 \mathrm{~h}$, respectively. The optimal temperature for growth was therefore $32^{\circ} \mathrm{C}$. The doubling time at that temperature was $0.9 \mathrm{~h}$, making strain DU-1 ${ }^{\mathrm{T}}$ one of the fastest-growing spiroplasmas known (9). No growth was recorded during a 40-day period in broth media incubated at 5 or $43^{\circ} \mathrm{C}$. Colonies (Fig. 1) of strain DU-1 $1^{\mathrm{T}}$ on $2.25 \%$ ("hard") agar were granular with some satellites; "fried-egg" colonies were never observed.

Dark-field microscopy of logarithmic-phase cultures of strain DU-1 ${ }^{\mathrm{T}}$ revealed numerous long helical motile filaments with six or more turns. As reported previously (18), electron microscopy revealed filamentous cells with no evidence of a cell wall. Representative cells were about 200 to $300 \mathrm{~nm}$ in diameter and were surrounded by a single membrane.

Sterol requirement. In the standard broth method used to measure growth responses to sterols, strain DU-1 ${ }^{\mathrm{T}}$ exhibited increased growth when cholesterol supplements were provided in serum-free base medium (Table 1). However, strain DU-1 ${ }^{\mathrm{T}}$ was able to maintain sustained growth for more than 23 serial passages in medium without serum or sterol supplements (12), suggesting that it does not have a specific growth requirement

TABLE 1. Growth response of strain DU-1 ${ }^{\mathrm{T}}$ to cholesterol ${ }^{a}$

\begin{tabular}{lcc}
\hline $\begin{array}{c}\text { Supplement(s) added to serum- } \\
\text { free base medium }\end{array}$ & $\begin{array}{c}\text { Cholesterol } \\
\text { concn }(\mu \mathrm{g} / \mathrm{ml})\end{array}$ & $\begin{array}{c}\text { Amt of protein } \\
(\mathrm{mg} / 100 \mathrm{ml})\end{array}$ \\
\hline $1 \%$ bovine serum fraction & Control & 3.76 \\
None & 0 & 0.19 \\
$1 \%$ albumin, 0.01\% Tween 80, & 0 & 0.45 \\
and $10 \mu \mathrm{g}$ of palmitic acid/ml & 1 & 0.76 \\
& 5 & 1.10 \\
& 10 & 1.44 \\
& 20 & 1.72 \\
\hline
\end{tabular}

${ }^{a} \mathrm{~A} 1 \%$ inoculum in bovine serum fraction broth was employed. All cultures were harvested after 2 days of incubation at $30^{\circ} \mathrm{C}$.
TABLE 2. Serological reactions and cross-reactions of strain DU-1 ${ }^{\mathrm{T}}$

\begin{tabular}{llccccr}
\hline \multirow{2}{*}{ Strain } & \multirow{2}{*}{ Group } & \multicolumn{2}{c}{$\begin{array}{c}\text { Spiroplasma deformation } \\
\text { test results }\end{array}$} & & \multicolumn{2}{c}{$\begin{array}{c}\text { Metabolism inhibition } \\
\text { test results }\end{array}$} \\
\cline { 3 - 4 } \cline { 6 - 7 } & & Antiserum & Antigen & & Antiserum & Antigen \\
\hline DW-1 & II & $<20^{a}$ & $<20^{b}$ & & $18^{c}$ & $<18^{d}$ \\
$23-6^{\mathrm{T}}$ & III & 80 & $80(10,240)^{e}$ & & $<18$ & $<18$ \\
MQ-1 $^{\mathrm{T}}$ & VII & $<20$ & $<20$ & & 486 & $<18$ \\
EA-1 & VIII-1 & $<20$ & $<20$ & & 18 & $<18$ \\
TAAS-1 & VIII-3 & $<20$ & $<20$ & & 18 & $<18$ \\
DU-1 & XII & $5,120^{f}$ & 5,120 & & $13,000^{\gamma}$ & 13,000 \\
LD-1 & XX & $<20$ & $<20$ & & 18 & $<18$ \\
BIUS-1 & & 1,280 & $<20$ & & 162 & $<18$ \\
PLHS-1 & & 80 & $<20$ & & 162 & $<18$ \\
PALS-1 & & $<20$ & $<20$ & & 54 & $<18$ \\
All others & $<20$ & $<20$ & & $<18$ & $<18$ \\
\hline
\end{tabular}

${ }^{a}$ Reciprocal of the endpoint in deformation tests in which the antigen of the strain was tested against the homologous antiserum.

${ }^{b}$ Reciprocal of the endpoint in deformation tests in which the antiserum to the strain was tested against the homologous antigen.

${ }^{c}$ Reciprocal of the endpoint in metabolism inhibition tests in which the antigen was tested against the homologous antiserum.

${ }^{d}$ Reciprocal of the endpoint in metabolism inhibition tests in which the antiserum was tested against the homologous antigen.

${ }^{e}$ The value in parentheses is the homologous titer of antisera against which strain DU- $1^{\mathrm{T}}$ cross-reacted when it was used as the antigen in heterologous tests.

${ }^{f}$ Homologous titer of strain DU-1 $1^{\mathrm{T}}$ in the test system. The values were obtained only once but are included for completeness.

for sterol. Several other Spiroplasma species or strains apparently lack a requirement for sterol for growth (12).

Biochemical and biological properties. Strain DU $-1^{\mathrm{T}}$ fermented glucose with production of acid, but no evidence of arginine or urea hydrolysis was observed. Passage of broth cultures of strain DU-1 ${ }^{\mathrm{T}}$ through 450 - or 300 -nm-pore-size membrane filters did not reduce the viable cell titer $\left(10^{9}\right.$ colorchanging units per $\mathrm{ml}$ ). The titer of a broth culture filtrate obtained after passage through a membrane with 220 -nm pores was reduced about 10 -fold (to $10^{8}$ color-changing units per $\mathrm{ml}$ ); the filtrate obtained after passage through a membrane with $100-\mathrm{nm}$ pores did not contain viable cells.

Serological tests. Metabolism inhibition and spiroplasma deformation tests (Table 2) demonstrated that strain DU-1 ${ }^{\mathrm{T}}$ was serologically unrelated to representatives of all previously recognized Spiroplasma species and groups and putative groups and subgroups (18). Moderate or large one-way cross-reactions were observed when antiserum directed against strain DU-1 ${ }^{\mathrm{T}}$ reacted with flower strain BIUS-1, scorpionfly strain PLHS-1, and dragonfly strain PALS-1. The cross-reactions with these strains were not significant, since antigens of these strains, all of which are candidates for group status (23), also reacted with antisera to a variety of other groups. Reciprocal cross-reactions in the DF test between strain DU-1 ${ }^{\mathrm{T}}$ and group III flower strain $23-6^{\mathrm{T}}$ (Spiroplasma floricola) suggested a possible lowlevel relationship, but this was not confirmed in MI tests. Since reciprocal reactivity in at least two serological cross-reactions is required to establish a relationship (22), our evidence indicates that strain DU-1 ${ }^{\mathrm{T}}$ is a representative of a distinct new Spiroplasma group.

Genomic characterization. The base composition (guanineplus-cytosine content) of the DNA of DU- $1^{\mathrm{T}}$ has been reported to be $25 \pm 1 \mathrm{~mol} \%$ (18), and the genome size has been reported to be $1,350 \mathrm{kbp}(2)$.

Phylogenetic position. Spiroplasma strain DU- $1^{\mathrm{T}}$ was shown to cluster with five other fast-growing insect-associated species (Spiroplasma monobiae, Spiroplasma taiwanense, Spiroplasma 
apis, Spiroplasma clarkii, and group XXIII strain TG-1, as determined by a sequence analysis (20) of $16 \mathrm{~S}$ rRNAs.

Habitat. Strain DU $-1^{\mathrm{T}}$ was isolated from the hemolymph of an adult southern corn rootworm beetle (cucumber beetle) with a heavy hemolymph infection, as determined by dark-field microscopy $(3,4)$. Larvae of the host beetle feed on the roots of corn and other grasses; adults feed on leaves, fruits, and flower tissues of many plant species. Noncultivable spiroplasmas have been observed regularly in the hemolymph of $\mathrm{Di}$ abrotica spp. from Maryland and Peru (7). Because strain DU $-1^{\mathrm{T}}$ grows extremely rapidly, it is very unlikely that the noncultivable spiroplasmas that have been observed are related to strain DU-1 ${ }^{\mathrm{T}}$. In several trials, strain DU-1 ${ }^{\mathrm{T}}$ infected Diabrotica balteata adults and Colorado potato beetle (Leptinotarsa decemlineata) adults. Strain DU-1 ${ }^{\mathrm{T}}$ is not known to be pathogenic to any of its hosts. Spiroplasmas have been considered for use as possible vectors for toxin genes (6); the Colorado potato beetle and its specific spiroplasma, group XX strain LD-1, have been used as a model (5).

The properties of strain DU $-1^{\mathrm{T}}$ described in this paper fulfill proposed criteria (8) for species belonging to the class Mollicutes (16). Properties mandating assignment to this class include the absence of a cell wall, filterability, and penicillin resistance. Two morphological features of strain DU- ${ }^{\mathrm{T}}$, helicity and motility, and the inability of strain DU $-1^{\mathrm{T}}$ to utilize urea place this organism in the family Spiroplasmataceae (13). Finally, a serological comparison of strain DU $-1^{\mathrm{T}}$ with representatives of other Spiroplasma species and groups demonstrated that this organism is a member of a distinct species. Accordingly, we propose the name Spiroplasma diabroticae for strain DU- ${ }^{\mathrm{T}}$. The taxonomic description below summarizes the properties of this new species.

Description of Spiroplasma diabroticae sp. nov. Spiroplasma diabroticae (di. a. bro' ti. cae. M.L. gen. n. diabroticae, from Diabrotica undecimpunctata, the chrysomelid beetle from which the organism was isolated).

Cells are filamentous, helical, and motile, vary from 200 to $300 \mathrm{~nm}$ in diameter, and lack true cell walls. Colonies on solid medium supplemented with $0.8 \%$ agar are diffuse, without fried-egg morphology.

Chemoorganotroph. Acid is produced from glucose. Does not hydrolyze arginine or urea.

Sterol is not required for sustained growth.

The temperature range is 10 to $41^{\circ} \mathrm{C}$; the optimum temperature is $32^{\circ} \mathrm{C}$.

Serologically distinct from other established Spiroplasma species, groups, and subgroups.

Isolated from the hemolymph of an adult chrysomelid beetle, D. undecimpunctata howardi.

The guanine-plus-cytosine content of the DNA is $25 \pm 1$ mol\%, and the genome size is $1,350 \mathrm{kbp}$.

The type strain is DU-1 (= ATCC 43210).

\section{ACKNOWLEDGMENT}

We thank Jeffrey L. Buller, Georgia Southern University, Statesboro, for his contribution concerning the specific epithet.

\section{REFERENCES}

1. Aluotto, B. B., R. G. Wittler, C. O. Williams, and J. E. Faber. 1970. Standardized bacteriologic techniques for characterization of Mycoplasma spe- cies. Int. J. Syst. Bacteriol. 20:35-58.

2. Carle, P., F. Laigret, J. G. Tully, and J. M. Bové. 1995. Heterogeneity of genome sizes within the genus Spiroplasma. Int. J. Syst. Bacteriol. 45:178181

3. Clark, T. B. 1984. Diversity of spiroplasma host-parasite relationships. Isr. J. Med. Sci. 20:995-997.

4. Clark, T. B., R. Henegar, L. Rosen, K. J. Hackett, R. F. Whitcomb, C. Saillard, J. M. Bové, J. G. Tully, and D. L. Williamson. 1987. New spiroplasma from insects and flowers: isolation, ecology, and host association. Isr. J. Med. Sci. 23:687-690.

5. Hackett, K. J., and T. B. Clark. 1989. The ecology of spiroplasmas, p. 113-200. In R. F. Whitcomb and J. G. Tully (ed.), The mycoplasmas, vol. 5. Academic Press, New York, N.Y.

6. Hackett, K. J., and J. J. Lipa. 1996. Mollicutes associated with the Chrysomelidae, p. 139-146. In P. Jolivet and M. L. Cox (ed.), Chrysomelidae biology, vol. 2. Ecological studies. SPB Academic Publishing, Amsterdam, The Netherlands.

7. Hackett, K. J., D. E. Lynn, and R. F. Whitcomb. 1988. Possible use of spiroplasmas in biological control, p. 93-98. In Proceedings of the Conference on Biotechnology, Biological Pesticides and Novel Plant-Pest Resistance for Insect Pest Management. Boyce Thompson Institute, Ithaca, N.Y.

8. International Committee on Systematic Bacteriology Subcommittee on the Taxonomy of Mollicutes. 1995. Revised minimum standards for descriptions of new species of the class Mollicutes. Int. J. Syst. Bacteriol. 45:605-612.

9. Konai, M., E. A. Clark, M. Camp, A. L. Koch, and R. F. Whitcomb. 1996 Temperature ranges, growth optima, and growth rates of Spiroplasma (Spiroplasmataceae, class Mollicutes) species. Curr. Microbiol. 32:1-7.

10. Markham, P. G., T. B. Clark, and R. F. Whitcomb. 1983. Culture techniques for spiroplasmas from arthropods. Methods Mycoplasmol. 2:217-223.

11. Razin, S., and J. G. Tully. 1970. Cholesterol requirements of mycoplasmas. J. Bacteriol. 102:306-310.

12. Rose, D. L., J. G. Tully, J. M. Bové, and R. F. Whitcomb. 1993. A test for measuring growth responses of mollicutes to serum and polyoxyethylene sorbitan. Int. J. Syst. Bacteriol. 43:527-532.

13. Skripal, I. G. 1983. Revival of the name Spiroplasmataceae fam. nov., nom rev., omitted from the 1980 Approved Lists of Bacterial Names. Int. J. Syst. Bacteriol. 33:408.

14. Tully, J. G. 1983. Tests for digitonin sensitivity and sterol requirement. Methods Mycoplasmol. 1:355-362.

15. Tully, J. G. 1983. Cloning and filtration techniques for mycoplasmas. Methods Mycoplasmol. 1:173-177.

16. Tully, J. G. 1989. Class Mollicutes: new perspectives from plant and arthropod studies, p. 1-31. In R. F. Whitcomb and J. G. Tully (ed.), The mycoplasmas, vol. 5. Academic Press, New York, N.Y.

17. Tully, J. G., and S. Razin (ed.). 1995. Molecular and diagnostic procedures in mycoplasmology, vol. 2, p. 460-462. Academic Press, San Diego, Calif.

18. Tully, J. G., D. L. Rose, E. Clark, P. Carle, J. M. Bové, R. B. Henegar, R. F. Whitcomb, D. E. Colflesh, and D. L. Williamson. 1987. Revised group classification of the genus Spiroplasma (class Mollicutes), with proposed new groups XII to XXIII. Int. J. Syst. Bacteriol. 37:357-364.

19. Tully, J. G., and R. F. Whitcomb. 1991. The genus Spiroplasma, p. 1960 1980. In A. Balows, H. G. Trüper, M. Dworkin, W. Harder, and K. H. Schleifer (ed.), The prokaryotes, 2nd ed., vol. 2. Springer-Verlag, New York, N.Y.

20. Weisburg, W. G., J. G. Tully, D. L. Rose, J. P. Petzel, H. Oyaizu, D. Yang, L. Mandelco, J. Sechrest, T. G. Lawrence, J. Van Etten, J. Maniloff, and C. R. Woese. 1989. A phylogenetic analysis of the mycoplasmas: basis for their classification. J. Bacteriol. 171:6455-6467.

21. Whitcomb, R. F. 1983. Culture media for spiroplasmas. Methods Mycoplasmol. 1:147-158.

22. Whitcomb, R. F., J. M. Bové, T. A. Chen, J. G. Tully, and D. L. Williamson. 1987. Proposed criteria for an interim serogroup classification for members of the genus Spiroplasma (class Mollicutes). Int. J. Syst. Bacteriol. 37:82-84.

23. Whitcomb, R. F., J. G. Tully, D. L. Williamson, J. M. Bové, F. E. French, M. Konai, G. Gasparich, M. Abalain-Colloc, C. Saillard, C. Chastel, P. Carle, D. L. Rose, R. Henegar, E. A. Clark, and K. J. Hackett. 1992. Revised classification of spiroplasmas. IOM Lett. 2:134.

24. Williamson, D. L., J. G. Tully, and R. F. Whitcomb. 1979. Serological relationships of spiroplasmas as shown by combined deformation and metabolism inhibition tests. Int. J. Syst. Bacteriol. 29:345-351

25. Williamson, D. L., J. G. Tully, and R. F. Whitcomb. 1989. The genus Spiroplasma, p. 71-111. In R. F. Whitcomb and J. G. Tully (ed.), The mycoplasmas, vol. 5. Academic Press, New York, N.Y.

26. Williamson, D. L., R. F. Whitcomb, and J. G. Tully. 1978. The spiroplasma deformation test, a new serological method. Curr. Microbiol. 1:203-207. 